\title{
Generation IV supercritical water-cooled nuclear reactors: Realistic prospects and research program*
}

\author{
Pavel L. Kirillov ${ }^{1}$, Galina P. Bogoslovskaya ${ }^{1}$ \\ 1 JSC «SSC RF-IPPE n.a. A.I. Leypunsky», 1 Bondarenko sq., Obninsk, Kaluga reg., 249033, Russian Federation \\ Corresponding author: Galina P. Bogoslovskaya (gpbogoslov@ippe.ru)
}

Academic editor: Yury Korovin • Received 15 October 2018 Accepted 20 December 2018 Published 11 April 2019

Citation: Kirillov PL, Bogoslovskaya GP (2019) Generation IV supercritical water-cooled nuclear reactors: Realistic prospects and research program. Nuclear Energy and Technology 5(1): 67-74. https://doi.org/10.3897/nucet.5.34293

\begin{abstract}
Existing conditions make possible obtaining information that being discussed openly by wide scientific community could help outlining or even establishing the expediency of a particular area of present and future research. Use link $\mathrm{http} / / / \mathrm{www} . s c i e n c e d i r e c t . c o m$ to learn about the topics or areas that most attract researchers from different countries.

The Generation IV International Forum (GIF-IV) established in January 2000 has set a goal to improve the new generation of nuclear technologies in the following areas: stability, safety and reliability, economic competitiveness, proliferation resistance and physical protection.

The purpose of the present publication is to prepare a discussion of one of the directions of development of fourth-generation NPPs, the groundwork for which has already been laid in thermal power engineering in various countries. The number of papers published annually on this topic is the largest among other similar topics dedicated to nuclear power plants of the fourth generation.

Judging from the operating experience of existing nuclear power plants using water as a coolant, it can be ascertained that the tendency of building water-cooled nuclear power plants will remain during the next 30 to 50 years. During the present stage the task in the development of alternative types of reactors will be limited to demonstration of their performance and acceptability for future power engineering and the society.

The project of supercritical water-cooled reactor is based on the operating experience of VVER, PWR, BWR reactors (more than 14,000 reactor-years); many years of experience accumulated in operating fossil thermal power plants (more than 400 power units; 20,000 years of operation of power units) using supercritical $\left(25 \mathrm{MPa}, 540^{\circ} \mathrm{C}\right)$ and super-supercritical $\left(35-37 \mathrm{MPa}, 620-700^{\circ} \mathrm{C}\right)$ water steam. In Russia more than 140 supercritical pressure units are currently in operation.

Numerical calculation and design of supercritical water-cooled reactor (similarly to BR-10 reactor) will allow not only training personnel for future development of this technology, but will also help revealing the most difficult points requiring experimental confirmation with application of independent test facilities, as well as formulating the plan of first priority experimental studies.

Knowledge accumulated over the last 10 years in the world allows the following: further specifying the already developed concept; developing a plan of specific priority studies; compiling task order for designing small-power pilot VVER SKP-30 reactor (30 MW-th).

The scope of problems that are to be solved to substantiate VVER-SCP reactor and commence designing an experimental reactor with thermal capacity of $30 \mathrm{MW}$ is the same as that in developing any type of nuclear reactor: physics of the reactor core; material related matters (primarily concerned with the reactor pressure vessel, fuel, and fuel rod
\end{abstract}


cladding); thermal hydraulics of rod bundles in the near- and supercritical areas; water chemistry at supercritical pressure; corrosion of materials, development of safety systems. Research must be carried out both in static conditions and under irradiation.

The absence in Russia during the extended time period of approved program with allocation of appropriate funding and preservation of the existing status during the coming two or three years will lead to the situation when Russia will be hopelessly lagging behind in the development of SCWR technology.

\section{Keywords}

GIF-IV program, supercritical water reactor (SCWR), prospects for nuclear power development, advantages of the VVER-SKP concept, problems of developing the VVER-SKP, proposals for cooperation, number of publications.

\section{Introduction}

Evolutionary development of NPPs with high thermal efficiency, high power reactors with improved fuel handling technology and service life of 50-60 years (Generation 3+) is continued during more than 25 years (Advanced Nuclear Power Reactors Generation III). VVER-1200, ABWR, APWR, AP-1000 and EPR (European Pressure Reactor) projects distinguished by their higher level of inherent safety and improved design of containment refer to such reactors. (Let us note that numerous inconsistences were revealed in the EPR project, which delays its implementation.)

American AP-1000 Project which has already passed through licensing is realized taking into account the new requirements and convincingly demonstrates the advantages of these reactors. Standard design consists of 50 larger and 250 smaller modules simultaneously manufactured and assembled at production facilities independently from each other. Overall construction period shrinks to 60 months. The project ensures low capital costs of construction, operation and control and guarantees high financial performance.

The Chernobyl catastrophe forced the designers to develop reactors with enhanced safety characteristics ensuring high level of reactor design including four safety levels, reactor building featuring doubled containment dome, passive trap in case of core melt.

\section{GIF-IV program}

GIF-IV (Generation-IV International Forum) Program (Russian acronym MFP-4) was developed in January 2000 under the initiative of the US DOE (Technology Roadmap Up Data for Generation IV, Pioro et al. in publication). Four main problems requiring resolution in the course of implementation of the Program were outlined: competitiveness, safety, nuclear wastes and ensuring non-proliferation of weapons materials.

The issue of the available resources of uranium became evident immediately after the beginning of construction of nuclear power stations. It was believed in the 19501960-ies that development of nuclear power generation will be limited by the availability of uranium. It is known that total resources of uranium on the Earth are abundant enough, uranium is found even in sea water but, however, the cost of uranium extraction from water is so high that this process proves to be non-feasible from financial standpoint. Therefore, estimation of uranium resources must be connected with the cost of uranium extraction. The following two cost estiamtions were accepted later: proven resources with extraction cost $<80 \$ / \mathrm{kg}$ and estimated resources $-80-130 \$ / \mathrm{kg}$. Main uranium reserves $(64 \%)$ are concentrated in the following four countries: Australia $-31 \%$, Kazakhstan - 12\%, Canada - 9\% and Russia - 9\%. According to the estimations made in 20152016 uranium resources in the world amount to 6-7 million tons. If converted into oil these reserves are equivalent to 363 billion tons of oil. If the above data are correct, then such amount of uranium is sufficient for supporting the development of nuclear power generation without fast reactors (for instance, sufficient for fueling 500 NPP units with annual consumption of about 100 thousand tons) during only the nearest 60 years (Uranium 2016).

The GIF-4 Program provides for the development of six new types of nuclear reactors of the next generation (Table 1). It was assumed that closed fuel cycle will be in place, i.e. that spent nuclear fuel will be re-used after reprocessing. It can be expected, though, that application of this complex and potentially dangerous technology will be limited during the coming years until its complete testing and fine tuning on a commercial scale.

The GIF-4 Program is targeted at the development of fast reactors with the potential implementation of closed fuel cycle and is aimed at the organization within the nearest years of the necessary scientific and technical background with subsequent realization of the projects during the second half or, more probably, by the end of this century. Recycling of spent nuclear fuel is regarded as the factor for saving energy resources for the future. However, use of reprocessed fuel may appear to be economically not profitable in the conditions of low cost of uranium. There exists fairly wide agreement with regard to the methods for reprocessing spent nuclear fuel (SNF), but, however, some large countries adhere as of today to the concept of open (once-through) nuclear fuel cycle 
preferring, as long as vast enough resources of uranium are still available, saving expenditures on the elaboration of reprocessing technologies and sending SNF to storage facilities. Serious economic assessments of the above two different ways for approaching the problem have not yet been made while their necessity within the next 20 years is obvious.

All the six types of reactors developed within the framework of the GIF-4 Program refer specifically to fast reactors capable to breed secondary nuclear fuel. Ten members of the program including Canada, China, Euratom, France, Japan, Russia, Switzerland, South Africa, South Korea and USA signed the framework agreement at government level. The above countries holding about $90 \%$ of NPP capacity in the world determine the main attributes of development of nuclear power generation in the future. It is noted in reports issued under the program for the years 2014-2017 that total expenditures on all six directions already amounted to US dollar millions.

The following two directions within the GIV program attract the most intense attention and are attempted to be developed with involvement of large efforts.

1. Sodium-cooled fast breeder reactor (SFR) (Handbook of Generation IV Nuclear Reactors 2016) allowing reducing the need in uranium by reaching the breeding ratio of about unity, is included in the national programs of several countries: Russia, China, France, India, Japan. $\mathrm{BN}-600$ reactor is successfully operated, $\mathrm{BN}-800$ reactor was commissioned in 2017, BN-1200 is under design in Russia. Two reactors (Phoenix and SuperPhoenix) were shut down in France, and ASTRID reactor with $600 \mathrm{MW}$ el. power is under development. The decision on the construction of this reactor was expected to be made in 2017, however, no decision has been made so far. PFBR reactor is under construction in India, the start-up of which was planned as early as in 2012. Pilot CEFR reactor is built in China, demonstration reactors CDFR-600 and CDFR1000 and commercial CDFBR-1200 reactor with metal fuel are under design. The program is based on the experience of operation of such reactors accumulated around the world amounting to more than 300 reactor-years.

Expenditures on the program of fast reactors in the world during only the period of 40 years (1950-1990) are estimated to exceed USD 50 billion, however, fast reactors did not achieve wide development since the 1990-ies.

2. Supercritical water-cooled reactor (SCWR) (Available at: https://www.gen-4.org/, Kirillov 2013, Baranaev et al. 2010) with thermal or intermediate neutron spectrum, water cooling under $25-\mathrm{MPa}$ pressure and steam outlet temperature equal to $500-540^{\circ} \mathrm{C}$. Transition to supercritical pressure allows combining the design of pressurized water-cooled reactor (PWR) and boiling reactor (BWR) within the unified concept. Such concept is proactively investigated in Canada, China, Europe and Japan. The main reasons for that include the possibility of obtaining higher thermal efficiency ( $44 \%$ and more), improved financial performance and solvability of safety problems. Development of reactors of this type is ongoing in 15 countries. Fundamental technological studies of fourth generation reactor planned to be started up in 2022 are completed in China. The main for this concept is the fact that it is based on the extensive world experience of operation of reactors cooled with water under subcritical pressure. Such NPPs constitute about $96 \%$ of the whole fleet of reactors in the world and have accumulated overall service time of 14,500 reactor-years. Mobile power units equipped with water-cooled reactors include about 450 sea vessels and submarines with operational experience of approximately 6,000 reactor-years. There already exists quite substantial experience of thermal power gen-

Table 1. Characteristics of Generation IV reactors under GIF-4

\begin{tabular}{|c|c|c|c|c|c|c|}
\hline Reactor & Coolant & $\begin{array}{l}\text { Temperature, } \\
{ }^{\circ} \mathrm{C} \\
\end{array}$ & $\begin{array}{c}\text { Pressure, } \\
\text { MPa }\end{array}$ & Fuel & $\begin{array}{l}\text { Power, } \\
\text { MW-el. }\end{array}$ & $\begin{array}{c}\text { Accumulated experience of operation, } \\
\text { years }\end{array}$ \\
\hline $\begin{array}{l}\text { GFR } \\
\text { Gas-Cooled } \\
\text { Fast Reactor }\end{array}$ & Helium & 850 & 7-14 high & $\mathrm{U}^{238}$ & 1200 & 53 \\
\hline $\begin{array}{l}\text { LFR } \\
\text { Lead-Cooled } \\
\text { Fast Reactor }\end{array}$ & Lead & $480-800$ & $\sim 2$ low & $\mathrm{U}^{238}$ and $\mathrm{UN}$ & $\begin{array}{c}20-180 \\
300-1200 \\
600-1000\end{array}$ & No \\
\hline $\begin{array}{l}\text { MSR } \\
\text { Molten Salt Fast Reactor }\end{array}$ & $\begin{array}{l}\text { Molten salt } \\
\text { fluorides }\end{array}$ & $700-800$ & $\sim 2$ low & UF & 1000 & 1.5 \\
\hline $\begin{array}{l}\text { SFR } \\
\text { Sodium-Cooled } \\
\text { Fast Reactor }\end{array}$ & Sodium & 550 & $\sim 2$ Low & $\begin{array}{l}\mathrm{U}^{238} \text { and } \\
\mathrm{MOX}\end{array}$ & $\begin{array}{c}300-1500 \\
1000-2000\end{array}$ & 360 \\
\hline $\begin{array}{l}\text { SCWR } \\
\text { Supercritical } \\
\text { Water-Cooled Reactor }\end{array}$ & Water & $510-625$ & 25 High & $\mathrm{UO}_{2}$ & $\begin{array}{c}300-700 \\
1000-1500\end{array}$ & $\begin{array}{l}\text { VVER, PWR, BWR } \sim 400, \text { number of } \\
\text { units } \sim 16000,400 \text { units of super- and } \\
\text { super-supercritical thermal power plants } \\
\sim 20000\end{array}$ \\
\hline $\begin{array}{l}\text { VHTR } \\
\text { Very High Temperature } \\
\text { Reactor }\end{array}$ & Helium & $650-1000$ & 7 high & $\mathrm{U}^{238}$ & $300-1200$ & 10 \\
\hline
\end{tabular}


eration operating thermal power plants (TPP) under supercritical pressure (about 400 power units around the world with total service time of more than 16000 unityears) (Fundamentals of contemporary power generation 2010). In the aggregate this gives about 36,000 years - the vastest operational experience of such power generating facilities operated under high pressure.

The majority of proposed options are associated with the use of direct thermal cycle (supply of steam from the reactor directly in the turbine as it is organized in boiling water reactors).

\section{Potential of development of nuclear power generation}

Main types of commercial nuclear reactors (May-June 2017) (Pioro and Kirillov 2015)

Thermal nuclear reactors: $81 \%$ - PWR, BWR, VVER $\left(\mathrm{H}_{2} \mathrm{O}\right)$; $11 \%$ - CANDU ( $\left.\mathrm{D}_{2} \mathrm{O}, \mathrm{H}_{2} \mathrm{O}\right)$; $4 \%$ - RMBK (graphite, $\mathrm{H}_{2} \mathrm{O}$ ); $3 \%$ - Gas-cooled (graphite, $\mathrm{CO}_{2}$ ).

Fast reactors:

$<1 \%-\mathrm{BN}-600, \mathrm{BN}-800$ (sodium).

$96 \%$ of all reactors from $100 \%$ are water-cooled.

Forecasted and actual rates of development of nuclear power generation according to estimates by IAEA experts made during different years (1985-2017) are shown in Figure 1.

Stabilization of the number of nuclear power units around the world took place during the last 15 years (450 power units in operation, 60-70 power units under construction). Reactors with expired service life are decommissioned. Uranium consumption is stabilized at the level of 60-70 thousand tons per year; inventory of already accumulated and currently produced uranium exceeds the

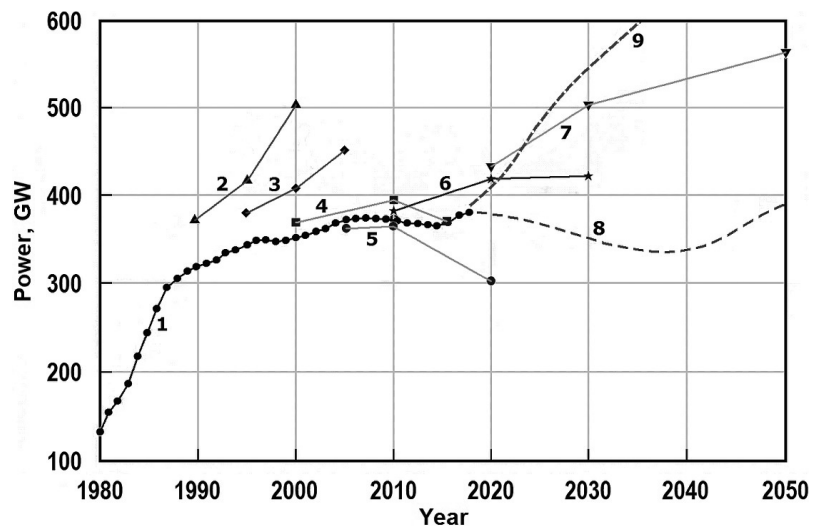

Figure 1. Forecasted and actual rates of development of nuclear power generation. 1 - actual power; IAEA forecasts of different years: 2-1985; 3-1990; 4-1995; 5-2000; 6-2005; 7-2010; 8-2017, 9-2018 (WNA forecast for 2050-1000 GW). demand. Uranium price plummeted during the last three years by almost two times (from $103 \$ / \mathrm{kg}$ in 2015 to 56 $\$ / \mathrm{kg}$ in 2017).

Under the existing conditions and forecasts (2017) explored uranium resources will be sufficient for the coming 100 years.

It is impossible to foresee subsequent development of nuclear power generation and the rate of this development beyond 15-20 years from now. There is no growth of production of electricity in the existing conditions, while the economy is converted to more energy saving technologies. As during the preceding periods attractiveness of these technologies will be determined independently by the needs, economy and politics of each country. However, two directions (sodium-cooled fast reactors (SFR) and water-cooled reactors with hard neutron spectrum (SCWR)) seem to be quite realistic during the next 30-50 years for subsequent development of nuclear power generation in the nearest future due to the degree of implementation of a number of their technologies in nuclear and thermal power generation as well as in combination with already existing and advanced systems.

Statistics of publications made during the last ten years on different directions of research as applicable to supercritical water-cooled reactors (SCWR) is represented in Table 2. Scientific analysis of these publications has yet to be done.

Papers presented in 2007-2017 during the conferences and workshops listed below:

- International Heat Transfer Conference (IHTC)

- International Conference on Nuclear Engineering (ICONE)

- International Topical Meeting on Nuclear Thermohydraulics (NUTHOS)

Table 2. List of scientific journals publishing papers on supercritical reactors during 2007-2017

\begin{tabular}{clc}
\hline $\begin{array}{c}\text { Item } \\
\text { no. }\end{array}$ & \multicolumn{1}{c}{ Titles of scientific journals } & $\begin{array}{c}\text { Number of } \\
\text { publications } \\
\text { in 2007-2017 }\end{array}$ \\
\hline 1 & Nuclear Engineering and Design & 175 \\
2 & Nuclear Engineering and Radiation Science & 36 \\
3 & Journal of Supercritical Fluids & 35 \\
4 & Transaction of ASME; Journal of Heat Transfer & 26 \\
5 & Applied Thermal Engineering & 15 \\
6 & International Journal Heat and Mass Transfer & 11 \\
7 & Nuclear Technology (ANS) & 10 \\
8 & Experimental Thermal and Fluid Science & 9 \\
9 & Energy Conversion and Management & 7 \\
10 & Materials Today & 4 \\
11 & International Journal Heat and Fluid Flow & 3 \\
12 & International Journal of Multiphase Flow & 1 \\
13 & International Seminar of Supercritical Water & $\sim 600$ \\
& Reactors ISSCWR № 3, 4, 5, 6, 7, 8 (2007-2017) & 10 \\
14 & Thermal Engineering & 8 \\
15 & Atomic energy & 3 \\
16 & Izvestiya vuzov. Yadernaya energetika (in & 504 \\
17 & Russian) & $\sim 1200$ \\
\hline & TAEA - TECDOC - 1746, 2014 & \\
\hline
\end{tabular}


- International Topical Meeting on Nuclear Reactor Thermohydraulics (NURETH)

- International Conference on Global Environment and Advance Nuclear Power Plants (GENES)

- International Congress on Advances on Nuclear Power Plants (ICAPP)

- Global Nuclear Future (GLOBAL)

As well as collected papers of the following meetings and workshops:

- GIF / SCWR Intern. Exchange Meetings 2012 и 2016 (IEM)

- INPRO Forum IAEA, 2016 (IF)

are not included in the list of publications dedicated to the subject under discussion

\section{Scientific and technical problems requiring resolution in the course of development of VVER SCP}

Let us address the list of problems required to be investigated for substantiating the VVER SCP (supercritical pressure) concept and for initiating the design of pilot reactor with 30-MW power, which seems to be sufficiently standard and obvious in designing any type of nuclear reactors (Ryzhov et al. 2009, Kalyakin et al. 2014, Alekseev et al. 2015, Schulenberg et al. 2014):

\section{Reactor core physics}

Main tasks:

- Determination of acceptable values of the breeding ratio (BR) and fuel burnup;

- Ensuring negative reactivity coefficients for different reactor operation modes;

- Ensuring inherent reactor self-protection.

Materials (structural materials, fuel composition, fuel cladding).

- Structural materials of reactor vessel (12X18H12T, O8X18H12T steels) have already been tested under fast neutron fluxes during the development and operation of $\mathrm{BR}-10, \mathrm{BOR}-60, \mathrm{BN}-600$ and $\mathrm{BN}-800$ reactors. It is expedient to implement analysis of the possibility to substitute these materials under different neutron spectra.

- Selected fuel - uranium dioxide $\mathrm{UO}_{2}$ - is widely used in different types of reactors and no issues emerging is case of use of this fuel composition in VVER SCP-30 reactors are anticipated so far.

- VVER SCP-30 fuel cladding materials are to be selected based on the experience of operation of fuel cladding of BN-60, BN-350 and BN-600 reactors. Quite probably these will be chrome-nickel alloys $(17 \mathrm{Cr}$, $13 \mathrm{Ni}, 2 \mathrm{Mo}$ ) for which it is necessary to implement estimation of their swelling for respective intensities of irradiation (dpa).

\section{Thermal hydraulics}

- The main feature of thermal hydraulics processes is the significant variation of water density and thermal capacity under supercritical parameters (SCP) $T_{\mathrm{c}}=$ $374,096^{\circ} \mathrm{C}, P_{\mathrm{c}}=22.064 \mathrm{MPa}, \mathrm{r}_{\mathrm{c}}=322 \mathrm{~kg} / \mathrm{m}^{3}$.

- For $P<P_{\mathrm{c}}$ and $P>P_{\mathrm{c}}$ the behavior of dependences of heat transfer and hydraulic resistance coefficients are well enough investigated as applied to simple forms of channels (round tubes, annular channels).

Investigation of thermal hydraulics of rod bundles in the areas of near critical and supercritical parameters is forthcoming.

It is difficult to measure these characteristics at near-critical parameters. At present uncertainty of calculations of heat transfer coefficients for simple forms of channels (round tube, flat slit) constitutes $\pm(15-20) \%$.

Such accuracy is sufficient for the initial phase of development, but, nevertheless, implementation of additional new experiments using water and simulation media (Freon) in channels of simple and complex forms and, first of all, investigation with tightly packed rod bundles (for instance, with pit equal to 1.1-1.15), are necessary.

Possibility of development of deteriorated heat exchange conditions and the affected area must be assessed and the methods for its mitigation (for instance, organization of flow vortices by spacer grids as in VVER reactor) must be tested.

Heat release densities $(\mathrm{kW} / \mathrm{l})$ and typical linear loads are practically similar for VVER and VVER SCP reactors (Table 3).

Table 3. Comparative parameters of VVER and VVER $\mathrm{SCP}$ reactors

\begin{tabular}{lcc}
\hline \multicolumn{1}{c}{ Heat release } & VVER & VVER SCP \\
\hline $\mathrm{q}_{\mathrm{v}}, \mathrm{kW} / \mathrm{l}$ & 110 & $\sim 110$ \\
$\mathrm{q}_{1}, \mathrm{~W} / \mathrm{cm}$ & $160-178$ & 160 \\
$\left(\mathrm{q}_{1}\right)_{\max }, \mathrm{W} / \mathrm{cm}$ & 448 & $\sim 300$ \\
\hline
\end{tabular}

Experiments must be performed for investigating heat exchange in tight rod bundles (with pit equal to 1.1-1.15) for developing more advance calculation methodologies.

Investigation of processes of intermixing of jets of "cold" $\left(T<T_{\mathrm{b}}\right)$ and "hot" $\left(T>T_{\mathrm{b}}\right)$ water is impending for determining unstable modes, if such modes will be found.

\section{Water chemistry (WC)}

Specific features of WC at SCP in boilers of thermal power plants are well enough worked out. Specifics of application in nuclear reactors of water at near-critical parameters is associated with effects of radiation and accompanying water radiolysis taking place in VVER, BWR, RBMK reactors.

Estimation and experimental investigation of the above phenomena in different neutron spectrum includ- 
ing mass transfer of corrosion products and radionuclides is forthcoming.

Corrosion of materials planned to be used in VVER SCP should be investigated both in static conditions and in supercritical water under radiation, i.e. directly in reactor circulation loops.

Problems of development of safety systems for VVER $\mathrm{SCP}$ reactor are similar to those addressed in the design of VVER reactors (active and passive safety systems).

The need to organize natural circulation within the reactor cooling loop using special devices or separate channels for heat removal can represent the specific feature of experimental VVER SCP-30 reactor.

Testing scientific and technical solutions pertaining to the design of VVER SCP reactor using scale models or full-scale testing of the design must be implemented.

Development and verification of computer software, including improved estimation codes for associated calculations of neutronics and thermal hydraulic characteristics of VVER SCP which will take into consideration the complex nature of variation of coolant properties within the limits of working temperatures $\left(t_{\text {in }}=350^{\circ} \mathrm{C}, t_{\text {out }}=550^{\circ} \mathrm{C}\right)$.

Proposals on cooperation on the SCP-related topics within the framework of the generation-IV international program

\section{JSC OKB "GIDROPRESS"}

"Materials and Chemistry" Group

- Material studies of experimental fuel PPC-Ts assemblies (Units I and II, Beloyarsk NPP).

- Presentation of results of previously implemented material studies.

\section{“Thermal-Hydraulics and Safety" Group}

- Investigation of heat transfer in the bundles of fuel pin imitators.

- Investigation of deformation of fuel pin cladding during transients.

\section{"System Integration and Assessment" Group}

- Design studies of experimental and pilot reactors.

\section{"Fuel and Fuel Cycle Options" Group}

- Design studies of fuel pin with dispersed fuel (The technology developed by the NPO "Luch").

\section{“Fast Core Option” Group}

- Cross-verification of computer software, calculation studies.

\section{JSC "SSC RF-IPPE"}

- Physics and thermal physics calculations.

- Preparation of experiments using BFS test facility.

- Modernization of the test stand for investigating hydrodynamic instabilities at SCP conditions.

- Preparation to experiments with supercritical water in the rod bundle.

- Construction of SCP loop on SM-3 reactor.
- Material studies experiments (subject to further specification upon completion of operations on the design of test stands and SCP loop).

- Design of experimental reactor.

RRC "Kurchatov Institute"

"Materials and Chemistry" Group

- Analytical review of the experience of the use of steels and alloys in SCP boilers in fossil fuel based power generation, water chemistry conditions and water preparation in the steam power loop.

\section{“Thermal-Hydraulics and Safety" Group}

- Selection of benchmark experiments for investigating thermal exchange in the tube with SCP water coolant and implementation of cross-verification of calculation instruments.

\section{"System Integration and Assessment" Group}

- Development of the concept of low-power multi-purpose research reactor.

\section{“Fuel and Fuel Cycle Options" Group}

- Implementation of assessment of technological capabilities for manufacturing different types of structural fuel cladding materials (VNIINM, NPO "Luch").

- Development of benchmark and implementation of cross-verification of computer software for the problem of fuel burnup and evolution of reactivity margin for reactor core with SCP water coolant.

\section{“Fast Core Option" Group}

- Development of benchmark for implementation of cross-verification of computer software for calculating neutronics characteristics of reactor cores with fast and variable neutron spectrum.

\section{Conclusions}

Design of supercritical water-cooled nuclear reactor VVER SCP-30 (Generation IV) or SCWR reactor according to the international classification is based on the following:

- Accumulated experience of operation of VVER, PWR and BWR reactors (more than 14,000 reactor-years);

- Many-year world experience of operation of thermal power plants (more than 400 power units, 20,000 unit-years) where water steam with supercritical (SCP) (25 MPa, 540 $\mathrm{S}$ ) and super-supercritical (35-37 MПа, 620-700 ${ }^{\circ} \mathrm{C}$ ) parameters is used. $\sim 140$ power units are operated in Russia under supercritical pressure (SCP).

Advantages of the VVER SCP concept are well known (Ryzhov et al. 2009, Kalyakin et al. 2014).

1. Hard (fast resonance) neutron spectrum allowing reaching high fuel breeding ratio (around 1) ensuring the use of ${ }^{238} \mathrm{U}$ and incineration of radioactive wastes. 
2. Efficiency of the thermodynamic cycle increased up to $44-45 \%$ instead of that for existing NPPs equal to 33-34\% (Thermal efficiency of modern thermal power plants is approaching 50-53\%).

3. Decreased coolant flow rate through the reactor core associated with the possibility of increasing coolant heating in the reactor core from $280{ }^{\circ} \mathrm{C}$ to $540^{\circ} \mathrm{C}$, i.e. by $270^{\circ} \mathrm{C}$ as compared to the heating in VVER equal to $30-35^{\circ} \mathrm{C}$. Decrease of flow rate reduces consumption of energy on coolant circulation, reduces the number of cooling loops (to two loops), reduces the flow cross-sections of pipelines (by 2.5-3 times), reduces the dimensions of shutoff and control valves, capacities and dimensions of main circulation pumps.

4. The problem of hydrogen safety is eliminated by the use of fuel cladding made of nickel alloys or stainless steels; the need of respective components of the above system (hydrogen sensors, re-combiners, etc.) is removed.

5. Straight through NPP layout reduces the numbers of equipment, allows rejecting steam generators in the secondary cooling circuit, pressurizers, pumps of the secondary cooling loops, separators.

6. Metal intensity of reactor facility is reduced by almost two times as compared with conventional reactor units, scopes and duration of construction works are reduced.

7. Containment volume is decreased which also reduces capital costs and duration of construction works.

Kurchatov Institute, OKB "Gidropress", OKBM and Dollezhal R\&D Institute of Power Engineering addressed this task during the expired period of 1964-1990 and later. However, these studies did not get enough momentum at the time. After the First International Seminar in Japan in 2000 SSC RF-IPPE initiated calculation efforts on reactor physics and thermal hydraulics. The obtained results were discussed on numerous occasions during interdepartmental and international workshops and conferences.

At present the development efforts are conducted in more than 15 countries (Japan, Korea, Canada, European Community, China, etc.). The draft of the International Program of Main R\&D Directions in this field was prepared and discussed by the meeting of the IAEA task team.

In 2011 Russia joined the International Cooperation including participation in the program of the International "Generation-IV" Forum (GIF-IV). However, up to the present moment works are performed only at the OKB "Gidropress", SSC RF-IPPE and RRC "Kurchatov Institute" as undertakings by enthusiasts using internal resources and small grants given by the Russian Foundation for Basic Research, IAEA and other entities.

OKB "Gidropress", SSC RF-IPPE and RRC "Kurchatov Institute" have developed in 2007 the basics of the concept (Ryzhov et al. 2011). Unfortunately, further developments were terminated.

However, analysis of foreign research proves their consistency, mutual coordination and, which is the most important, their ability to provide trained personnel in advance. The foreign training centers including Mac-Master University (Hamilton, Canada), Internation- al Centre for Theoretical Physics at Miramar-Trieste (Italy) jointly with IAEA conduct special training courses on the SCWR design and technology. The objective of the courses is to educate instructors for training future specialists specifically in this direction of development of nuclear energy (Available at: https://www.iaea.org/).

International symposia where practical issues related to the SCWR concepts and achievements of certain research groups are discussed, are conducted for already active experts (Baranaev et al. 2007, Baranaev et al. 2015, Duffey et al. 2008, Ruzickova et al. 2008, IAEA-TECDOC, Ser. No.1746 2014, Makhin and Churkin 2017, Makhin et al. 2014) in the following specific areas:

- Reactor physics;

- Materials, water chemistry and corrosion;

- Thermal hydraulics;

- Reactor safety;

- Heat cycles of NPPs equipped with VVER SCP reactors, outstanding issues and the methods for their resolution.

The VI International Forum on SCWR (ISSCWR-6) took place in March, 2013 in Shenzhen (China), the VII Forum took place in Helsinki in March, 2015, and the VIII Forum was held in May, 2017 in Chengdu (China). The next forum (ISSCWR-9) will take place in March, 2019 in Vancouver (Canada).

In accordance with the information obtained from the Head of the Department of International Cooperation of the Nuclear Power Institute of China (NPIC, Chengdu), the Chinese Ministry for Technology and Science allocated funds for the SCWR Project. It is planned to organize in the nearest future in China systematic works under this project with allocation of annual funding. Chinese leadership made a decision to turn the NPIC into the largest in the world nuclear research institute and undertook practical implementation of this objective.

Development of the complex program of VVER SCP studies within the framework of the Rosatom State Corporation is expedient with nomination of persons responsible for separate sections of the program and definition of the financing procedures. Joint proposal by the OKB "GIDROPRESS", SSC RF-IPPE and the RRC "Kurchatov Institute" on the draft of the above program was presented on numerous occasions during the GIF-IV Steering Committee Meetings on SCWR.

Knowledge accumulated during the last 10 years allows the following:

- Further specification of previously developed concept; - Compiling the plan of specific first priority studies;

- Preparation of the statement of work on the design of small-power test VVER SCP-30 reactor (30 MW-th).

Calculation and design of such reactor (similarly to BR-10 reactor) will allow not only training personnel for future development of the relevant technology, but, additionally, revealing the most difficult aspects requiring experimental substantiation using separate test facilities, as well as the plan of first priority experimental studies. 


\section{References}

- Advanced Nuclear Power Reactors (2018) Advanced Nuclear Power Reactors Generation III+ Nuclear Reactors - World Nuclear Association. http://www.world-nuclear.org [accessed Apr 10, 2018]

- Alekseev P, Semchenkov Y, Sedov A, Sidorenko V, Silin V, Mokhov V, Nikitenko M, Makhin V, Churkin A (2015) Conceptual Proposals on VVER-SCW Reactor Developed on the Basis of VVER Technologies and Steam-Turbine Installations at Supercritical Parameters. The VII-th International Symposium on Supercritical Water-Cooled Reactors ISSCWR-7. Helsinki, Finland. Report ISSCWR7-№ 2055 .

- Baranaev YD, Glebov AP, Dolgov EV (2007) Comparative analysis of the physical characteristics of the VVER-SKD reactor with oneand two-way coolant flow patterns: IPPE Prepint-3110. Obninsk, FEI Publ., 21 pp. [in Russian]

- Baranaev YD, Glebov AP, Klushin AV (2015) Prospects for the use of VVER-SKD in a closed fuel cycle. Izvestia Vysshikh Uchebnykh Zavedeniy. Yadernaya Energetika 1: 5-19. [in Russian]

- Baranaev YD, Glebov AP, Kirillov PL, Klushin AV (2010) Supercritical water cooled reactor VVER-SKD - The main contender in "Super-VVER": IPPE Preprint -3188. FEI Publ., Obninsk, 19 pp. [in Russian]

- Duffey RB, Pioro I, Zhou T, Zirn U, Kuran S, Khartabil H, Naidin M (2008) Supercritical Water-Cooled Nuclear Reactors (SCWRs): Current and Future Concepts - Steam-Cycle Options. Proc. ICONE-16, Orlando, Paper \#48869, 9 pp.

- IAEA-TECDOC, Ser. No.1746 (2014) Heat Transfer Behavior and Thermo hydraulics Code Testing for Supercritical Water Cooled Reactors (SCWRS).

- ICTP-IAEA Workshop (2018) Joint ICTP-IAEA Workshop on Physics and Technology of Innovative Nuclear Energy Systems. https://www.iaea.org/events/joint-ictp-iaea-workshop-on-physics-and-technology-of-innovative-nuclear-energy-systems [accessed Apr 10, 2018]

- Kalyakin SG, Kirillov PL, Baranaev YuD, Glebov AP, Bogoslovskaya GP, Nikitenko MP, Makhin V M, Churkin AN (2014) Prospects for the Development of an Innovative Water-Cooled Nuclear Reactor for Supercritical Parameters of Coolant. Teploenergetika 61(8): 551-557. [in Russian]

- Kirillov PL (2013) Water-cooled VVER SKD reactor (preliminary development). Izvestia Vysshikh Uchebnykh Zavedeniy. Yadernaya Energetika 1: 5-14. [in Russian]

- Makhin VM, Churkin AN (2017) Conceptual proposals for a supercritical water-cooled reactor (review of foreign and Russian developments of SCWR). The X International Scientific and Technical
Conference "Safety Assurance of NPP with VVER" (MNTK-2017). Report mntk-152, Podolsk. [in Russian]

- Makhin VM, Mokhov VA, Berkovich VYa, Nikitenko MP, Churkin AN, Lapin AV, Kirillov PL, Baranaev YuD, Glebov AP (2014) Conceptual proposals on VVER-SCP reactor prototype test facility. VANT. Ser.: Obespechenie besopasnosti AES 34: 84-92. [in Russian] - Pioro IL, Duffey RB, Kirillov PL, Pioro R, Zvorykin A, Machrafi R (2019) Current Status and Future Developments in Nuclear-Power Industry of the World. Nuclear Engineering and Radiation Science. [in publication]

- Pioro IL (2016) Handbook of Generation IV Nuclear Reactors (1 ${ }^{\text {st }}$ edn). Woodhead Publishing Series in Energy, 940 pp.

- Pioro IL, Kirillov PL (2015) Nuclear power - the basis of future electricity production. Izvestia Vysshikh Uchebnykh Zavedeniy. Yadernaya Energetika 2: 5-23. [in Russian]

- Ruzickova M, Hajek P, Smida S, Vsolak R, Petr J, Kysela J (2008) Supercritical water loop design for corrosion and water chemistry tests under irradiation. Nuclear Engineering and Technology 40(2): 27-132. https://doi.org/10.5516/NET.2008.40.2.127

- Ryzhov SB, Kirillov PL, Mokhov VA, Nikitenko MP, Chetverikov AE, Makhin VM, Glebov AP, Churkin AN (2011) Concept of a Single Circuit RP with Vessel Type SCWR. Report on the Vth Intern. Symp. (ISSCWR-5). Paper P076. Canada, Vancouver, March 13-16.

- Ryzhov SB, Mokhov VA, Vasilchenko IN, Nikitenko MP, Makhin BM, Lapin AV, Chetverikov AE, Churkin AN, Anikeev YuA, Shmelev SB (2009) Problems in the development of supercritical water-cooled reactor core (VVER-SKP). VANT. Ser.: Obespechenie bezopasnosti AES. Reaktornye ustanovki s VVER-SKD 25: 5-14. [in Russian]

- Schulenberg T, Leung L, Oka Y (2014) Review of R\&D for supercritical water cooled reactors. Progress in Nuclear Energy 77: 282 299. https://doi.org/10.1016/j.pnucene.2014.02.021

- SCWR (2018) Supercritical-Water-Cooled Reactor (SCWR). https:// www.gen-4.org/gif/jcms/c_40679/technology-system-scwr [accessed Apr 10, 2018]

- Technology Roadmap Up Data for Generation IV. Nuclear Energy Systems. OECD (2014) http://www.gif_tru2014.pdf [accessed Apr 10, 2018]

- Trukhny A (2010) Fundamentals of Contemporary Power Generation (2 Vols) -Modern Heat Generating System (Vol. 1). MEI Publ., Moscow, 422 pp. [in Russian]

- Uranium (2016) Resources, Production and Demand. / A Joint Report by the Nuclear Energy Agency and the International Atomic Energy Agency. NEA No. 7301. OECD. 